\title{
Route of entry and tissue distribution of Yersinia ruckeri in experimentally infected rainbow trout Oncorhynchus mykiss
}

\author{
E. Tobback ${ }^{1, *}$, A. Decostere ${ }^{1}$, K. Hermans ${ }^{1}$, J. Ryckaert $^{2}$, L. Duchateau ${ }^{3}$, \\ F. Haesebrouck ${ }^{1}$, K. Chiers ${ }^{1}$ \\ ${ }^{1}$ Department of Pathology, Bacteriology and Avian Diseases, Ghent University, Salisburylaan 133, 9820 Merelbeke, Belgium \\ ${ }^{2}$ Department of Animal Production, Ghent University, Rozier 44, 9000 Ghent, Belgium \\ ${ }^{3}$ Department of Physiology and Biometrics, Ghent University, Salisburylaan 133, 9820 Merelbeke, Belgium
}

\begin{abstract}
Yersinia ruckeri is the causative agent of enteric redmouth disease, which leads to significant losses in salmonid aquaculture worldwide. Despite the significance of the disease, little information is available on the pathogenesis. In this study, the portal of entry was investigated using a contact-exposure infection method in rainbow trout Oncorhynchus mykiss with 4 different Y. ruckeri strains. Bacteriological and histological examination revealed the presence of high numbers of bacteria in the gills immediately after infection resulting in a rapid spread of $Y$. ruckeri in the internal organs. However, only a virulent strain was able to survive and multiply in the host, causing septicaemia and death several days after infection. These findings indicate that gills may be an important site of entry and that $Y$. ruckeri virulence is related to immune evasion.
\end{abstract}

KEY WORDS: Yersinia ruckeri $\cdot$ Portal of entry $\cdot$ Virulence $\cdot$ Rainbow trout

\section{INTRODUCTION}

Yersinia ruckeri is the causative agent of yersiniosis, or enteric redmouth disease (ERM), and causes significant losses in salmonid aquaculture worldwide. Although infection with this agent has been reported in other fish species, salmonids (especially rainbow trout) are most susceptible to ERM (Furones et al. 1993). Infection may result in the development of a chronic or acute septicaemia with haemorrhages on the body surface and in the internal organs.

Despite the importance of ERM, little is known about the precise pathogenic mechanisms by which Yersinia ruckeri is able to defeat the host defences and cause disease. Differences in virulence between $Y$. ruckeri strains after experimental infection studies in rainbow trout have been documented by using intraperitoneal and intramuscular injection as well as contact exposure (Davies 1991, Romalde \& Toranzo 1993, Austin et al. 2003, Fouz et al. 2006). This last method, however, seems a more reliable and efficacious infection model which mimics the conditions of natural infection as accurately as possible and ensures that immune mechanisms located at the body surface play their role. Nevertheless, it has not been determined yet how and when rainbow trout are infected by $Y$. ruckeri and where the bacterium resides in the infected fish.

The purpose of this study was to reveal the route of entry of Yersinia ruckeri in rainbow trout (Expt 1) and to investigate its tissue distribution at different time intervals (Expt 2) after experimental infections with 4 different $Y$. ruckeri isolates. Additional experimental infections (Expts 3a and 3b) were carried out to determine whether a different tissue distribution is related to differences in virulence. These virulence studies were performed at 2 different temperatures, since temperature is known to have an impact on rainbow trout immune-related functions, as well as on Y. ruckeri growth and the production of toxins (Nikoskelainen et al. 2004, Fernández et al. 2007). 


\section{MATERIALS AND METHODS}

Bacterial strains. We used 4 different Yersinia ruckeri strains in the experiments. Strain 5 was originally isolated in 2001 from rainbow trout farmed in the UK with clinical signs of ERM and was obtained from the Institute of Aquaculture (Stirling, Scotland). Strains 17.00(2-1) and E842-95 were provided by L'Institut National de la Recherche Agronomique (INRA, Paris, France). Strain 17.00(2-1) was isolated from a rainbow trout without clinical manifestation. No background information was available about Strain E842-95. Type Strain CCUG 14190 was obtained from the culture collection of the University of Göteborg (Sweden) and was isolated from a rainbow trout with ERM. All the strains belong to serotype O1a except for Y. ruckeri E842-95, which is a serotype O1b strain as characterized by J. L. Romalde (Universidad de Santiago de Compostela, Spain).

Stock suspensions of the strains were stored at $-70^{\circ} \mathrm{C}$. After thawing, the bacteria were grown overnight at $20^{\circ} \mathrm{C}$ on Columbia agar (Oxoid) with $5 \%$ sheep blood (blood agar). Colonies were picked up from the agar plates and grown in nutrient broth (NB, VWR) for $24 \mathrm{~h}$ at $20^{\circ} \mathrm{C}$. The number of colony forming units (CFU) per ml was determined by plating 10 -fold serial dilutions on blood agar plates.

Animals. We obtained 4 batches (Expts 1, 2, 3a and $3 \mathrm{~b}$ ) of $30,81,85$ and 120 rainbow trout, weighing 6 to $45 \mathrm{~g}, 22$ to $55 \mathrm{~g}, 3$ to $20 \mathrm{~g}$ and 8 to $60 \mathrm{~g}$, respectively, from a fish farm (Gérouville, Belgium) with no history of ERM disease. The fish were acclimatized for $10 \mathrm{~d}$ and maintained in $1000 \mathrm{l}$ tanks in filtered, recirculated tap water. They were fed daily with a commercial diet (Vijver Visvoeder). To ensure that animals were free from Yersinia ruckeri, $10 \%$ of the trout of each newly introduced batch was sacrificed and samples from gills, gut, liver, kidney and spleen were taken for bacteriological examination. Furthermore, before the start of each experiment, swabs were taken from the skin, fins and gills of 2 randomly chosen fish for microscopic evaluation of external parasites. Y. ruckeri was not isolated on blood agar from any sample and all fish were free of external parasitic infestations.

Experimental infections. All the experimental infections were approved by the ethical committee of the Faculty of Veterinary Medicine, Ghent University (EC2005/73, EC 2007/094, EC 2008/026).

In Expt 1, groups of 6 fish were bath-challenged with either Yersinia ruckeri strain 5, 17.00(2-1), CCUG 14190 or E842-95 (4 groups in total) at a final concentration of approximately $2 \times 10^{8} \mathrm{CFU} \mathrm{ml}{ }^{-1}$. After $1 \mathrm{~h}$ of contact exposure in aerated aquaria at $18^{\circ} \mathrm{C}$, the fish were transferred to their tanks again. At time points 0 , 1.5 and $2.5 \mathrm{~h}$ post-infection (PI), 2 fish from each infec- tion group were euthanized using an overdose of a stock solution of benzocaine (1 $\mathrm{g}$ ethyl aminobenzoate [Federa] in $10 \mathrm{ml}$ of acetone). After euthanasia, fish were rinsed with tank water to remove non-adherent bacteria from skin and gills. Six control fish were not infected and were kept under the same conditions, from which 2 were sampled at every time point in the same way as the infected fish.

In Expt 2, groups of 18 trout were contact-exposed to a final concentration of approximately $2 \times 10^{7} \mathrm{CFU} \mathrm{ml}^{-1}$ of the 4 Yersinia ruckeri strains for $1 \mathrm{~h}$ at $18^{\circ} \mathrm{C}$ in the same way as in Expt 1. Two fish of each infection group were sampled at $1,2,4,6,9,12,24,48$ and $72 \mathrm{~h}$ PI. Nine control fish were kept under the same conditions as the infected fish, from which 1 was sampled at every time point.

In Expt 3a, 4 groups of 20 fish were contact-exposed for $1 \mathrm{~h}$ at $23^{\circ} \mathrm{C}$ in the same way as in Expt 1 . The final concentrations were approximately 2 to $3 \times 10^{7} \mathrm{CFU}$ $\mathrm{ml}^{-1}$ of the 4 Yersinia ruckeri strains. Five control fish were kept under the same conditions as the infected fish. After inoculation, fish were observed for clinical signs several times a day and mortality was recorded. Dead and moribund fish were necropsied. The remaining fish were euthanized between 14 and $18 \mathrm{~d}$ PI.

In Expt 3b, 4 groups of 25 fish were contact-exposed for $1 \mathrm{~h}$ at $16^{\circ} \mathrm{C}$ in the same way as in Expt 1 . The final concentrations were approximately $10^{7} \mathrm{CFU} \mathrm{ml}^{-1}$ of the 4 Yersinia ruckeri strains. Twenty control fish were kept under the same conditions as the infected fish. As in Expt 3a, dead and moribund fish were necropsied and the remaining fish were euthanized between 20 and $34 \mathrm{~d}$.

In all the experiments, samples of gills, proximal and distal gut, liver, kidney and spleen were collected for bacteriological, histological and immunohistochemical examination. In Expts 1 and 2, additional samples of middle gut were taken and $1 \mathrm{~cm}^{2}$ skin tissue along the left lateral line below the dorsal fin was collected from all fish in Expt 1.

Bacteriological examination. The collected tissues were homogenized in phosphate-buffered saline (PBS) as $10 \%(\mathrm{w} / \mathrm{v})$ suspensions. The number of CFU Yersinia ruckeri $\mathrm{g}^{-1}$ liver, kidney and spleen was determined by plating 10 -fold dilutions of the suspensions on blood agar plates. Dilutions of gills, gut and skin suspensions were inoculated on MacConkey agar plates (Oxoid). Y. ruckeri was identified based on the typical colony shape and negative oxidase reaction. Systematically, identification of 1 colony of a suspected $Y$. ruckeri isolate of each plate was also confirmed using PCR.

PCR analysis. DNA was extracted from a loopful of cells using an alkaline lysis method (Baele et al. 2000). PCR was carried out using the primers YER8 
(5'-GCG AGG AGG AAG GGT TAA GTG-3') and YER10 (5'-GAA GGC ACC AAG GCA TCT CTG-3'), which amplify a $575 \mathrm{bp}$ fragment of the 16S rRNA gene of Yersinia ruckeri, as previously described by Gibello et al. (1999). For each PCR reaction, $1 \mu \mathrm{l}$ of the prepared DNA was added to $9 \mu$ of the PCR mixture,

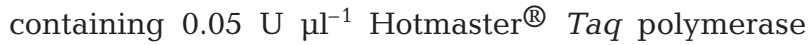
(Eppendorf), 10× PCR buffer (Invitrogen Life Technologies), $25 \mathrm{mM} \mathrm{MgCl}_{2}$ (Invitrogen), $200 \mu \mathrm{l}$ of each deoxynucleoside triphosphate (Amersham Pharmacia Biotech), $0.5 \mu \mathrm{M}$ of each primer (Operon) and sterile distilled water. The used conditions for the amplifications were the following: an initial denaturation at $94^{\circ} \mathrm{C}$ for $5 \mathrm{~min}$, followed by 35 cycles of denaturation at $94^{\circ} \mathrm{C}$ for $1 \mathrm{~min}$, annealing at $61^{\circ} \mathrm{C}$ for $1 \mathrm{~min}$ and extension at $72^{\circ} \mathrm{C}$ for $1 \mathrm{~min}$. A final extension was performed at $72^{\circ} \mathrm{C}$ for $8 \mathrm{~min}$. PCR products were run in agarose gels containing $1.5 \%$ Multi Purpose agarose (Boehringer) in $1 \times$ Tris-borate-EDTA (TBE) buffer, pH 8 and stained with ethidium bromide. The gels were visualised using the Image Master VDS ${ }^{\circledR}$ (Amersham Pharmacia Biotech).

Histological and immunohistochemical analysis. In Expt 1, tissue samples were fixed in Carnoy's solution (60\% ethanol, 30\% chloroform, 10\% acetic acid) for at least $2 \mathrm{~h}$, dehydrated in an alcohol-xylene series and embedded in paraffin wax. The organs in Expts 2, 3a and $3 \mathrm{~b}$ were fixed in $10 \%$ phosphate buffered formaldehyde for at least $24 \mathrm{~h}$ before being dehydrated and embedded. Five- $\mu$ m sections, mounted on glass slides, were stained with haematoxylin and eosin (H\&E) and Giemsa.

Additionally, immunohistochemistry was performed, using polyclonal rabbit anti-Yersinia ruckeri antibodies. Hyperimmune serum was obtained by immunizing rabbits (EC 2005/921) with Y. ruckeri strain 7 as described by Decostere et al. (1999). Five- $\mu$ m sections of paraffin-embedded tissues were placed on SuperFrost slides (Sigma-Aldrich), deparaffinized, rehydrated and pretreated by the antigen retrieval microwave technique. Thereafter, slides were incubated with endogenous peroxidase and were washed once with PBS. Slides then underwent sequential application of $30 \%$ goat serum, primary rabbit anti- Y. ruckeri strain 7 1/800 antibody, biotinylated goat anti-rabbit antibody 1/500 (DakoCytomation), StreptABComplex/ horseradish peroxidase (DakoCytomation), and finally 3,3'-diamino benzidine tetrahydrochloride (SigmaAldrich) with each time a wash step. Sections were counterstained by use of an aqueous-based haematoxylin staining and mounted.

Statistical analysis. In Expts 1 and 2, a fixed effects model (SAS Version 9.1.3) was used to compare CFU Yersinia ruckeri $\mathrm{g}^{-1}$ tissue using first time and strain as fixed effects and the organ as stratification factor, then time and organ as fixed effects and the strain as stratification factor. The analysis was done at the $5 \%$ global significance level and the reported p-values for pairwise comparisons are adjusted using Tukey's multiple comparisons method.

In Expts 3a and 3b, the analysis of the time to death outcome was based on the Wilcoxon rank sum test with all surviving fish given the same and highest rank. First, the time to death outcome was compared between the different contact exposed groups within each experiment. Second, the time to death outcome was examined between the 2 experiments for each strain. As the normal distribution assumption did not hold, the Wilcoxon signed-rank test was used to compare CFU Yersinia ruckeri $\mathrm{g}^{-1}$ tissue between the different organs of the fish using only animals from which $Y$. ruckeri was isolated from at least 1 organ.

\section{RESULTS}

\section{Expt 1}

Bacteriological examination. For Expt 1, the highest bacterial numbers were reisolated from the gills (Fig. 1). These numbers were significantly higher than these reisolated from the gut between 0 and $2.5 \mathrm{~h}$ PI for strains $5(\mathrm{p}=0.0005)$ and 17.00(2-1) $(\mathrm{p}=0.0016)$. For Yersinia ruckeri strains 5, 17.00(2-1) and CCUG 14190, the bacterial numbers reisolated from the gills, skin and gut declined between 0 and $1.5 \mathrm{~h}$ PI and remained the same or increased slightly between 1.5 and $2.5 \mathrm{~h}$ PI. Higher bacterial numbers were detected in the skin than in the gut at $0,1.5$ and $2.5 \mathrm{~h} \mathrm{PI}$ in fish inoculated with these strains; however, only for Strain 5 was the amount of bacteria in the skin significantly higher $(\mathrm{p}=$ $0.0035)$ than in the gut over this time period.

For Yersinia ruckeri E842-95, the bacterial population in the gills declined gradually between 0 and $2.5 \mathrm{~h}$ PI. The number of bacteria reisolated from the gut also showed a gradual decrease in this time period; however, the bacterial population in the skin increased slightly between 0 and $1.5 \mathrm{~h} \mathrm{PI}$, after which a sharp decrease was observed. Differences in bacterial numbers between these organs were not statistically significant between 0 and $2.5 \mathrm{~h}$ PI. Bacteria were also found in liver, kidney and spleen (between $10^{1}$ and $10^{5} \mathrm{CFU} \mathrm{g}^{-1}$ ) of all fish immediately after infection with Y. ruckeri strains 5, 17.00(2-1), CCUG 14190 and E842-95 and fluctuated between $0 \mathrm{~h}$ and $2.5 \mathrm{~h}$ PI (data not shown).

Histological and immunohistochemical analysis. Histopathological changes were not observed in any of the tissues of fish at $0,1.5$ and $2.5 \mathrm{~h}$ after contact exposure to Yersinia ruckeri strains 5, 17.00(2-1), CCUG 



Fig. 1. Yersinia ruckeri infecting Oncorhynchus mykiss. Detection of Y. ruckeri in gills, gut (posterior, middle and anterior gut were pooled) and skin of rainbow trout after contact challenge with Strains (a) 5, (b) 17.00(2-1), (c) CCUG 14190 and (d) E842-95 at $0,1.5$ and $2.5 \mathrm{~h}$ post-infection (PI). Each time point represents the means of 2 fish. The number of bacteria in each sample is expressed as $\log \left(\mathrm{CFU} \mathrm{g}^{-1}\right.$ tissue $)$

14190 and E842-95, which were compared with those of negative control fish. Giemsa and immunohistochemical staining revealed the presence of Y. ruckeri bacteria in the gills of several fish inoculated with Strain 5. At time $0 \mathrm{~h}$ PI, numerous bacteria were observed in the mucus of the primary and secondary lamellae, whereas later on, a lower number of bacteria was found. At time 0 and $2.5 \mathrm{~h}$ PI, 2 fish showed the presence of a few bacteria in the capillaries of the secondary lamellae (Fig. 2a). In the gut of trout inoculated with $Y$. ruckeri strain 5, few bacteria were noticed in the crypts, attached to the villi and within the mucosa at different time points (Fig. 2b).

A notably lower number Yersinia ruckeri bacteria (as low as none) were detected in the gills and gut of fish inoculated with Strains 17.00(2-1), CCUG 14190 and E842-95. Bacteria were observed in the mucus of the gills and in the crypts and the mucosa of the gut sections. Y. ruckeri was not detectable in the skin, liver, kidney and spleen of infected fish by histology or immunohistochemistry.

Fig. 2. Yersinia ruckeri infecting Oncorhynchus mykiss. (a) Localisation of Strain 5 at $0 \mathrm{~h}$ post-infection (PI) in (a) a capillary of the gill filament (Giemsa stain) and (b) the intestinal lumen between the villi and in the mucosa (immunohistochemical staining)

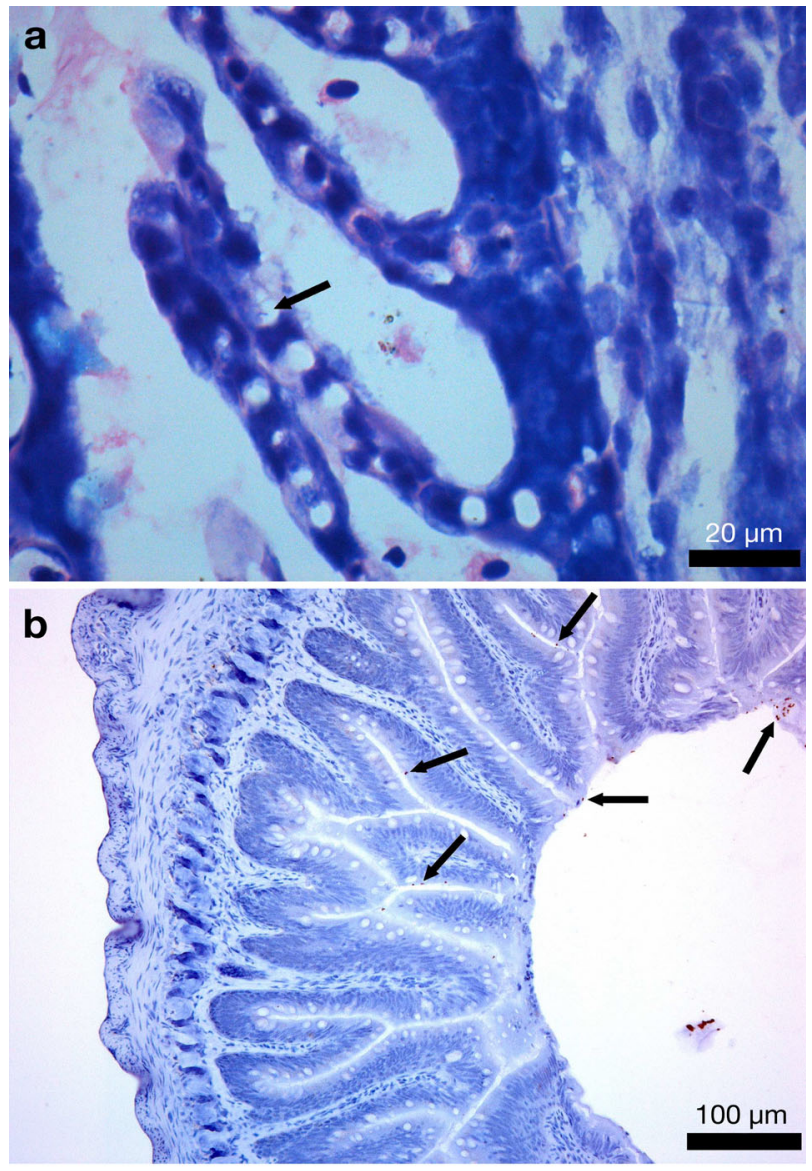




\section{Expt 2}

Bacteriological examination. For Expt 2, the highest numbers of bacteria were reisolated from the gills of trout contact-exposed to Yersinia ruckeri strains 5, 17.00(2-1), CCUG 14190 and E842-95 during the first $2 \mathrm{~h}$ PI (Figs. 3 \& 4). After a period of fluctuations in the bacterial population, bacteria were no longer detectable in the gill tissue at 24, 48, 12 and $48 \mathrm{~h}$ PI for Strains 5, 17.00(2-1), CCUG 14190 and E842-95, respectively. However, in the gills of fish inoculated with $Y$. ruckeri strain 5, the number of bacteria sharply increased between 48 and $72 \mathrm{~h}$ PI, whereas bacteria were not isolated from the gills of fish from the other infection groups.

The number of bacteria reisolated from the gut of fish inoculated with Yersinia ruckeri strains 17.00(2-1) and E842-95 was low during the first $12 \mathrm{~h}$ PI. Bacterial numbers in the gut of these fish were slightly higher at 24 to $48 \mathrm{~h}$ PI and exceeded the amounts reisolated from the gills at this time. By comparison, the number of bacteria in the gut of fish inoculated with $Y$. ruckeri strain 5 was higher within the first $12 \mathrm{~h}$ PI and sharply increased between 48 and $72 \mathrm{~h}$ PI. In the gut of fish inoculated with Strain CCUG 14190, none or only small amounts of bacteria were reisolated between 1 and $72 \mathrm{~h} \mathrm{PI}$.

Bacteria were found in the liver, kidney and spleen of fish contact-exposed to Yersinia ruckeri strain 5 between 1 and $72 \mathrm{~h}$ PI. The number of bacteria fluctuated with a peak on $6 \mathrm{~h}$ PI for the 3 tissues (between $1.2 \times 10^{4}$ and $2.4 \times 10^{4} \mathrm{CFU} \mathrm{g}^{-1}$ ) and a sharp increase in bacterial population between 48 and $72 \mathrm{~h}$ PI was noticed. By comparison, lower bacterial numbers $\left(\leq 4.0 \times 10^{1} \mathrm{CFU} \mathrm{g}^{-1}\right)$ were reisolated from liver, kidney and spleen of fish challenged with $Y$. ruckeri strains 17.00(2-1) and CCUG 14190 before 9 and $24 \mathrm{~h} \mathrm{PI}$, respectively. Thereafter, bacteria were no longer detected in these organs. A similar trend was seen in the liver, kidney and spleen of fish inoculated with Strain E842-95, however, slightly higher amounts of bacteria were reisolated from these tissues between 1 and $24 \mathrm{~h}$ PI.

The number of bacteria in the gills was significantly higher than in the gut $(p=0.0006)$, liver $(p<0.0001)$, kidney $(p=0.0003)$ and spleen $(p<0.0001)$ from fish inoculated with Strain 17.00(2-1). Also for Strain CCUG 14190, significantly higher numbers were observed in the gills than in the gut $(p=0.0033)$, liver $(\mathrm{p}=0.0051)$, kidney $(\mathrm{p}=0.0058)$ and spleen $(\mathrm{p}=$ 0.0042 ). Significantly more bacteria were reisolated from the liver of fish inoculated with Strain 5 than from the liver of fish inoculated with Strains 17.00(2-1) $(\mathrm{p}=$ 0.0003), E842-95 ( $\mathrm{p}=0.0338)$ and CCUG 14190 ( $\mathrm{p}=$ 0.0001). The spleen and kidney of fish infected with Strain 5 also showed significantly higher numbers of bacteria compared to the spleen and kidney of fish
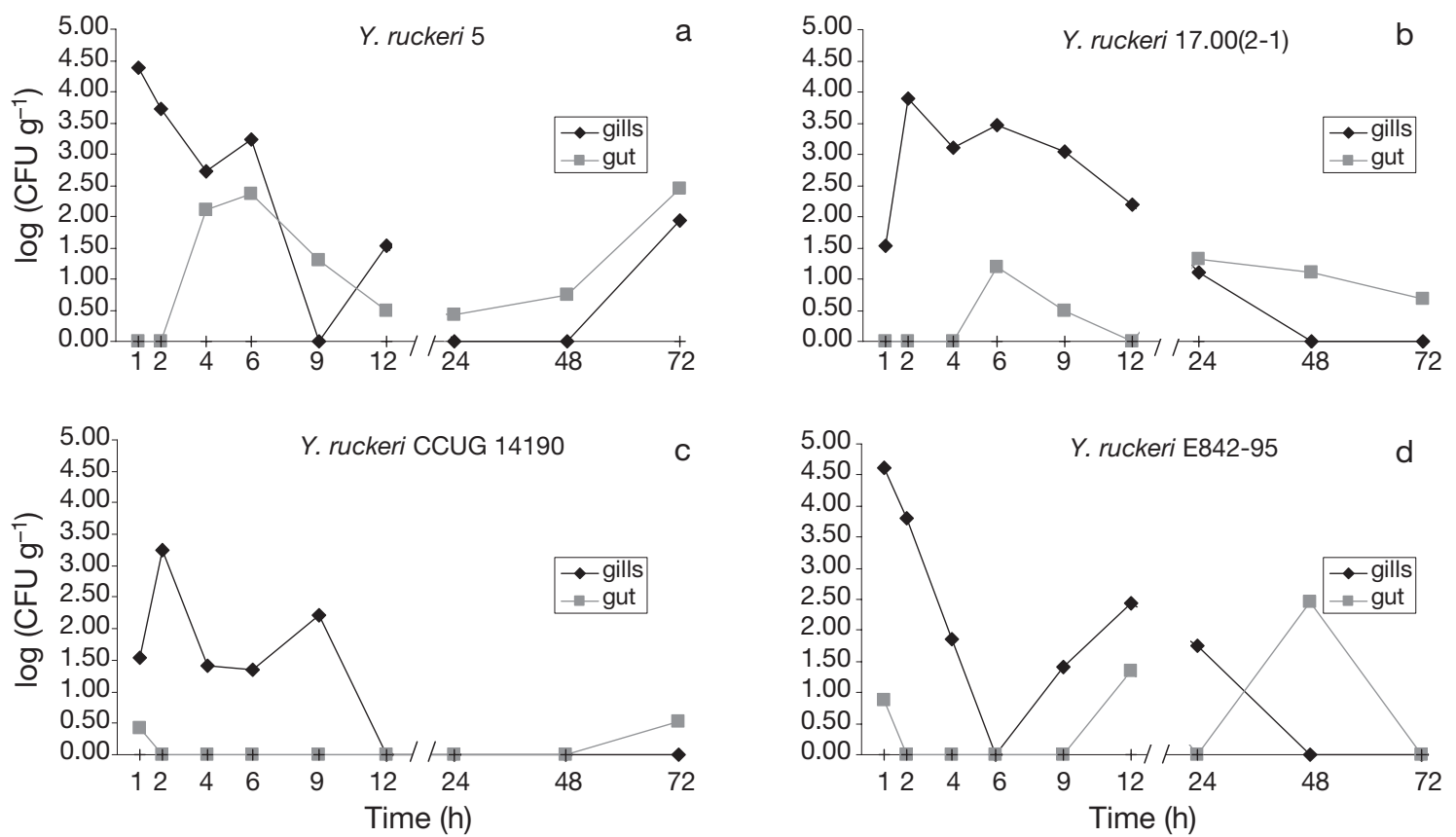

Fig. 3. Yersinia ruckeri infecting Oncorhynchus mykiss. Detection of Y. ruckeri in gills and gut (posterior, middle and anterior gut were pooled) of rainbow trout after contact challenge with Strains (a) 5, (b) 17.00(2-1), (c) CCUG 14190 and (d) E842-95 at 1, 2, 4 , $6,9,12,24,48$ and $72 \mathrm{~h}$ post-infection (PI). Each time point represents the means of 2 fish. The number of bacteria in each sample is expressed as $\log \left(\mathrm{CFU} \mathrm{g}{ }^{-1}\right.$ tissue $)$ 



Fig. 4. Yersinia ruckeri infecting Oncorhynchus mykiss. Detection of Y. ruckeri in liver, kidney and spleen of rainbow trout after contact challenge with strains (a) 5, (b) 17.00(2-1), (c) CCUG 14190 and (d) E842-95 at 1, 2, 4, 6, 9, 12, 24, 48 and 72 h post-infection (PI). Each time point represents the means of 2 fish. The number of bacteria in each sample is expressed as

$$
\log \left(\mathrm{CFU} \mathrm{g} \mathrm{g}^{-1} \text { tissue }\right)
$$

infected with Strains 17.00(2-1) $(\mathrm{p}=0.0002$ and 0.0025 , respectively) and CCUG $14190(\mathrm{p}=0.0002$ and 0.0002 , respectively). At $72 \mathrm{~h} \mathrm{PI}$, fish contact-exposed to $Y$. ruckeri 5 had significantly ( $p<0.0083$ ) higher bacterial numbers in the liver, kidney and spleen than those infected with the other strains.

Histological and immunohistochemical analysis. Histopathological changes were not observed in any of the tissues of fish between 1 and $72 \mathrm{~h}$ after contact exposure to Yersinia ruckeri strains 5, 17.00(2-1), CCUG 14190 and E842-95, which were compared with these of negative control fish. Bacteria were not detected by histological and immunohistochemical analysis.

\section{Expts 3a and 3b}

Clinical signs, mortality and necropsy findings. Disease signs or mortality were not noted among the fish belonging to the control groups of Expts 3a and 3b. In both experiments, clinical signs and/or mortality were only observed in rainbow trout inoculated with Yersinia ruckeri strain 5 (Table 1). In Expt 3a, 6 of the 20 fish contact-exposed to $Y$. ruckeri strain 5 died within 5 to $11 \mathrm{~d}$ PI, with the highest rate at $7 \mathrm{~d}$ PI. They did not show any additional clinical signs. The surviving fish neither showed clinical signs or lesions. In Expt 3b, four out of 25 fish contact-exposed to Y. ruckeri strain 5 died within $9 \mathrm{~d}$ PI with a mean of $7.8 \mathrm{~d}$ PI.

Table 1. Yersinia ruckeri infecting Oncorhynchus mykiss. Results of clinical and bacteriological examination of rainbow trout experimentally infected with Strain 5, using the immersion-challenge method. Only the organs of dead fish were included. PI: post-infection

\begin{tabular}{|c|c|c|c|c|c|c|c|c|c|c|}
\hline \multirow{2}{*}{$\begin{array}{l}\text { Expt/ } \\
\text { Strain }\end{array}$} & \multirow{2}{*}{ Total } & \multirow{2}{*}{$\begin{array}{c}\text { No. of fish } \\
\text { With clinical } \\
\text { signs }\end{array}$} & \multirow[b]{2}{*}{ That died } & \multirow{2}{*}{$\begin{array}{l}\text { Mean time } \\
\text { of death } \\
\text { (d PI) }\end{array}$} & \multicolumn{6}{|c|}{ No. of Y. ruckeri $\log _{10} \mathrm{CFU} \mathrm{g}^{-1}$ tissue (mean $\pm \mathrm{SE}$ ) isolated } \\
\hline & & & & & Gills & $\begin{array}{l}\text { Proximal } \\
\text { gut }\end{array}$ & $\begin{array}{l}\text { Distal } \\
\text { gut }\end{array}$ & Liver & Spleen & Kidney \\
\hline $\begin{array}{l}\text { Expt 3a } \\
5 \\
\text { Expt 3b }\end{array}$ & 20 & 0 & 6 & 7.2 & $5.5 \pm 1.1$ & $8.6 \pm 2.1$ & $7.5 \pm 1.1$ & $7.0 \pm 0.5$ & $8.2 \pm 1.2$ & $7.2 \pm 0.5$ \\
\hline 5 & 25 & 2 & 4 & 7.8 & $8.0 \pm 2.5$ & $7.4 \pm 2.5$ & $7.4 \pm 2.4$ & $7.8 \pm 1.9$ & $7.8 \pm 1.9$ & $7.8 \pm 1.9$ \\
\hline
\end{tabular}


Two of these fish showed exopthalmia accompanied by orbital haemorrhages and 1 had an enlarged liver and spleen.

In both immersion experiments, Strain 5 showed significantly higher mortality $(\mathrm{p}<0.0001)$ compared to the other strains. There was no significant difference between the 2 experiments with respect to time to death for any of the strains.

Bacteriological examination. In Expts $3 a$ and $3 b$, Yersinia ruckeri was not isolated from the organs of the control fish. In Expt 3a, Y. ruckeri was reisolated from gills, proximal and distal gut, liver, spleen and kidney of all 6 fish that died after contact-challenge with Strain 5 in the range of $10^{5}$ to $10^{8} \mathrm{CFU} \mathrm{g}^{-1}$ tissue (Table 1). The bacterium was reisolated from one or more organs from 4 fish that survived after contact exposure to $Y$. ruckeri strain 5 in the range of $10^{2}$ to $10^{3} \mathrm{CFU} \mathrm{g}^{-1}$ tissue, being found most often in the spleen. In Expt 3b, Y. ruckeri was reisolated from gills, proximal and distal gut, liver, spleen and kidney of all 4 fish that died after contact-challenge with Strain 5 in the range of $10^{7}$ to $10^{8} \mathrm{CFU} \mathrm{g}^{-1}$ tissue (Table 1 ). In 1 surviving fish, euthanized $21 \mathrm{~d}$ after contact exposure, $1.7 \times 10^{2}$ and $8.3 \times 10^{2} \mathrm{CFU}$ of $Y$. ruckeri strain $5 \mathrm{~g}^{-1}$ tissue was reisolated from kidney and spleen, respectively.

Trout inoculated with Yersinia ruckeri strains 17.00(2-1), CCUG 14190 or E842-95 never showed the presence of the bacterium in their organs at euthanasia. No differences in CFU Y. ruckeri $\mathrm{g}^{-1}$ gills, proximal and distal gut, liver, spleen and kidney were observed in animals exposed to Strain 5.

Histological and immunohistochemical analysis. Since only Strain 5 caused disease and mortality in vivo, the tissue samples of fish infected with this strain were analysed by histology and immunohistochemistry. Tissue samples of some fish that died were susceptible to post-mortem decay and therefore difficult to interpret. Samples that were too deteriorated were not included in the results. To analyse histopathological changes, samples of infected fish were compared with those of negative control fish.

Similar results for Expts $3 \mathrm{a}$ and $3 \mathrm{~b}$ were observed. Almost all fish that died after infection showed a moderate to severe oedema in the secondary lamellae, whereas the gills of trout that survived exhibited a lower degree or no oedema. Multifocal to coalescing coagulative necrosis (Fig. 5a) was observed in the spleen of almost all dead animals with the presence of numerous intralesional bacteria. Only 1 fish that survived contact exposure to Yersinia ruckeri strain 5 showed a very mild focal necrosis in its spleen. In the kidneys of several surviving fish, contact-exposed to Strain 5, degeneration and/or mild necrosis of proximal tubules (Fig. 5b) were observed. These findings were rarely present in kidneys of dead fish. Increased cellularity of the glomerular tuft was present in a small number of animals that died or survived contact exposure to Strain 5. In the kidney, there were slight to
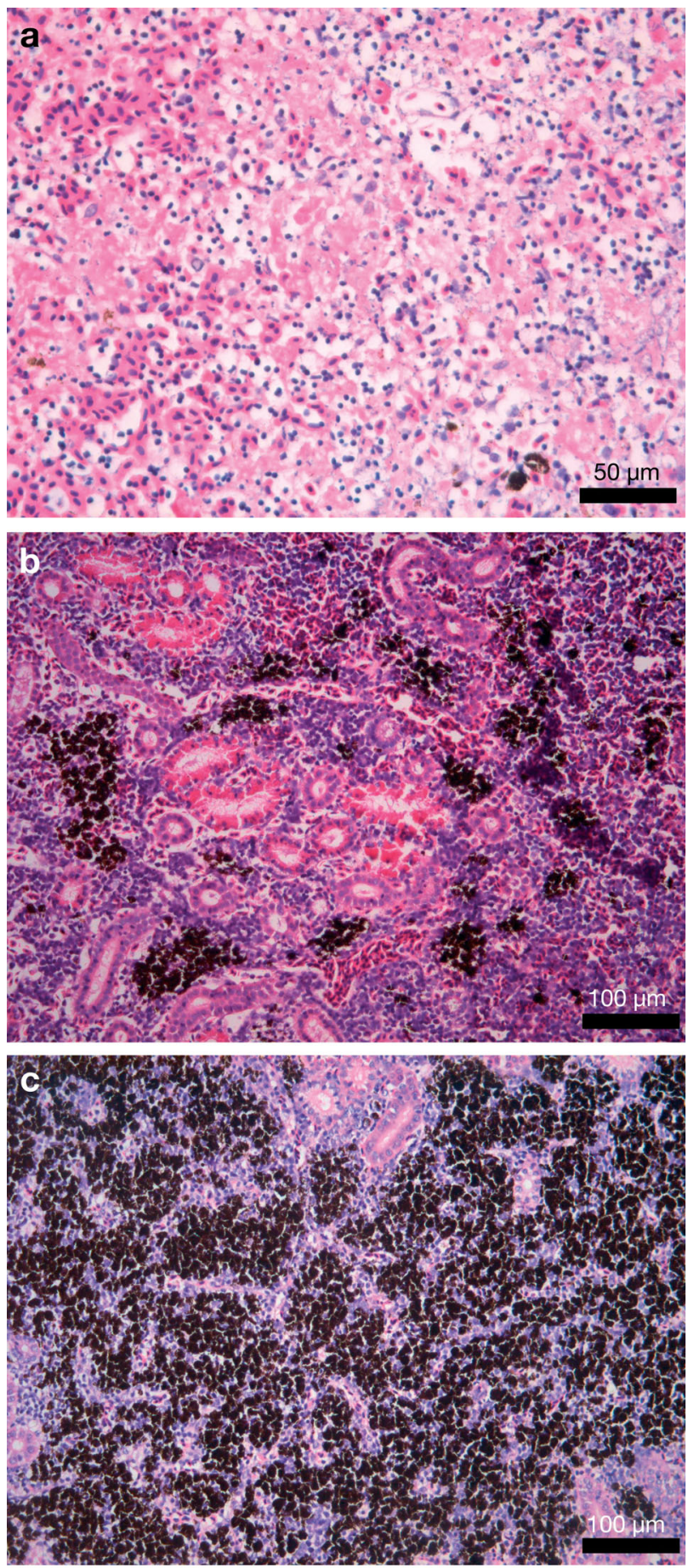

Fig. 5. Yersinia ruckeri infecting Oncorhynchus mykiss. H\&E staining of (a) spleen with coagulative necrosis, (b) kidney with degenerated tubules and (c) kidney with a notable increase in melanomacrophages of a rainbow trout that died $3 \mathrm{~d}$ post-infection (PI) after contact exposure to Strain 5 
moderate increases in the number of macrophages of the majority of fish that survived after infection. A minority of trout that died after infection also showed a slight increase in the number of macrophages. A notable increase in melanomacrophages (Fig. 5c) was also observed in about half of the fish that died or survived after infection with Strain 5. No histopathological changes were seen in the gut or the liver.

Immunohistochemistry revealed the presence of bacteria in all organs from which Yersinia ruckeri was isolated. In the spleen, bacteria were mainly found in or surrounding the necrotic areas. In all other organs, bacteria were randomly distributed extracellularly. In the liver, however, bacteria were also found intracytoplasmic.

PCR analysis. The isolates that were identified as Yersinia ruckeri by colony morphology in all experiments were confirmed to be $Y$. ruckeri by PCR.

\section{DISCUSSION}

Attachment and entry into the host's body is the first requirement for a bacterial pathogen to establish an infection. To investigate this early interaction between bacteria and its host using histological and immunohistochemical techniques, it is important to maintain the tissue morphology optimally. Carnoy's fixative has been shown to preserve the surface mucous gel layer covering surface mucous cells in different internal organs (Ota \& Katsuyama 1992, Shimizu et al. 1996, Matsuo et al. 1997). Since adhesion of Yersinia ruckeri to mucus may be important during the early stages of infection, tissue samples in Expt 1 were fixed in Carnoy's solution.

Attachment of Yersinia ruckeri to the gill mucus was obviously seen soon after infection, whereas fewer bacteria were detected in the mucus in the course of time. Y. ruckeri was also observed within the gill capillaries at $0 \mathrm{~h}$ as well as $2.5 \mathrm{~h}$ PI. This may indicate that bacteria first adhere to gill mucus and thereafter invade the branchial vasculature leading to septicaemia and colonization of the internal organs. Torroba et al. (1993) showed that formalin-killed $Y$. ruckeri were taken up by gill epithelial cells during an in vitro assay where isolated rainbow trout gills were placed in medium containing the killed bacteria. Zapata et al. (1987) demonstrated that killed Y. ruckeri bacteria were taken up by the gill cells of Atlantic salmon after bath immunization. However, results obtained with dead bacteria may differ from these with viable bacteria. The uptake of live Y. ruckeri bacteria by the gill epithelium was demonstrated by the use of an isolated perfused rainbow trout head model (McIntosh et al. 2000). The results of the pre- sent in vivo studies demonstrate that gills may indeed be an important portal of entry. Gills have also been reported as a site of entry for other septicaemic fish pathogens, such as Vibrio anguillarum and Edwardsiella tarda (Baudin-Laurencin \& Germon 1987, Ling et al. 2001). For respiration, gills are highly vascularized, with a large number of blood capillaries; therefore, they may provide good entry sites for bacteria to become easily disseminated to the entire body of the fish (Ling et al. 2001).

Although the gills are apparently an important portal of entry for Yersinia ruckeri, the bacterium may also successfully colonize other body surfaces and gain entry to the body by a variety of routes, including the skin and the gut, as suggested by Busch \& Lingg (1975) and Valtonen et al. (1992). In our study, moderate numbers of $Y$. ruckeri were isolated from the skin and gut immediately after infection. At histological examination, some bacteria were noticed in the intestinal crypts, indicating that they evaded the first line of host defences in the gut mucosa. Further studies are warranted to determine the role of the skin and the gut as portals of entry.

Infection resulted in a rapid spread of Yersinia ruckeri into the internal organs. Other fish pathogens like Edwardsiella tarda and Vibrio anguillarum have also been reisolated from different organs within $1 \mathrm{~h}$ after contact exposure (Spanggaard et al. 2000, Ling et al. 2001). In the present study (Expt 2), a sharp increase in reisolated $Y$. ruckeri from the internal organs was observed 3 d after infection with Strain 5. Only for this strain, mortality appeared from $5 \mathrm{~d}$ PI onwards, with high bacterial numbers present in these organs (Expts 3a and 3b). In contrast, no or only a few bacteria were detected in the internal organs of fish infected with the other strains at this time and clinical signs and mortality were not observed. Comparable results were seen in blue gourami Trichogaster trichopterus after contact exposure to Edwardsiella tarda. Infection with a virulent strain resulted in an exponential proliferation of the bacterial population in all examined tissues and organs until Day 3, when mortalities in infected fish were observed. After immersion with a non-virulent strain that did not induce mortality, however, the number of bacteria declined over a $7 \mathrm{~d}$ period within all the tissues (Ling et al. 2001). Our findings demonstrate that differences in virulence exist and suggest that the immune system is able to clear non-virulent $Y$. ruckeri bacteria from the organs of the fish. Possibly, virulent isolates are attacked by immune cells, resulting in a temporary decrease in the number of bacterial cells within the organs. Survival and proliferation of virulent Y. ruckeri in immune cells or in the blood might result in a subsequent increase of bacteria causing 
severe septicaemia and death. Therefore, it would be interesting to study the interaction with macrophages as well as the serum resistance of the different $Y$. ruckeri strains.

Different factors may influence the outcome of a bacterial infection, including the temperature. Yersinia ruckeri was found to cause significant losses in the field at water temperatures of 15 to $18^{\circ} \mathrm{C}$ (Roberts 1983). Danley et al. (1999) observed a higher incidence of infection at $18^{\circ} \mathrm{C}$ than at $22^{\circ} \mathrm{C}$ in channel catfish Ictalurus punctatus (Rafinesque) intraperitoneally injected with $Y$. ruckeri. Increased severity of infection may be due to upregulation of different $Y$. ruckeri virulence factors at lower temperatures, as has been demonstrated by Fernández et al. (2007). However, in the present study, contact exposures of trout to Y. ruckeri at 16 and $23^{\circ} \mathrm{C}$ did not result in a significantly different outcome as measured by clinical signs, bacteriological and histological analysis. Possibly other factors, such as the infection dose and fish size, may have played a role.

The increase of melanomacrophages in the kidney of some infected fish in our studies has not previously been described. Within melanomacrophage centres, macrophages have been shown to destroy and kill the fungus Candida albicans but also to phagocytose rainbow trout erythrocytes in the immediate vicinity (Passantino et al. 2002). Consequently, melanomacrophage centers seem to play an important role in the elimination of foreign particulate material and of fish erythrocytes that have ingested microorganisms. Melanomacrophages are believed to be a prominent feature of chronic inflammatory responses (Ferguson 2006). Therefore, our results could indicate a possible role of Yersinia ruckeri in chronic nephritis.

In conclusion, gills may be an important site of entry for Yersinia ruckeri during infection of rainbow trout. Probably the bacteria first adhere to the gill mucus, after which they invade the branchial vasculature and subsequently spread into the internal organs very soon after infection. Virulent strains are probably able to defeat the host immune mechanisms, leading to high bacterial load and necrosis in the organs resulting in death of the fish several days after infection. Exposure to non-virulent strains, however, results in a complete removal of bacteria from the internal organs. This could indicate that immune evasion is a major virulence property of $Y$. ruckeri.

Acknowledgements. J. L. Romalde is acknowledged for providing the serotypes of the bacterial strains. The technical assistance of D. Ameye, C. Puttevils, S. Loomans, M. Foubert and V. Flama is gratefully appreciated. This study was supported by The Research Fund of Ghent University, Belgium, grant no. 01110505.

\section{LITERATURE CITED}

Austin DA, Robertson PAW, Austin B (2003) Recovery of a new biogroup of Yersinia ruckeri from diseased rainbow trout (Oncorhynchus mykiss, Walbaum). Syst Appl Microbiol 26:127-131

Baele M, Baele P, Vaneechoutte M, Storms V and others (2000) Application of tRNA intergenic spacer PCR for identification of Enterococcus species. Am Soc Microbiol 38:4201-4207

> Baudin-Laurencin F, Germon E (1987) Experimental infection of rainbow trout, Salmo gairdneri R., by dipping in suspensions of Vibrio anguillarum: ways of bacterial penetration; influence of temperature and salinity. Aquaculture 67:203-205

Busch RA, Lingg AJ (1975) Establishment of an asymptotic carrier state infection of enteric redmouth disease in rainbow trout (Salmo gairdneri). J Fish Res Board Can 32: 2429-2432

> Danley ML, Goodwin AE, Killian HS (1999) Epizootics in farm-raised channel catfish, Ictalurus punctatus (Rafinesque), caused by the enteric redmouth bacterium Yersinia ruckeri. J Fish Dis 22:451-456

Davies RL (1991) Virulence and serum-resistance in different clonal groups and serotypes of Yersinia ruckeri. Vet Microbiol 29:289-297

> Decostere A, Haesebrouck F, Charlier R, Ducatelle R (1999) The association of Flavobacterium columnare strains of high and low virulence with gill tissue of black mollies (Poecilia sphenops). Vet Microbiol 67:287-298

Ferguson HW (2006) Systemic pathology of fish. In: Ferguson HW (ed) Systemic pathology of fish: a text and atlas of normal tissues in teleosts and their responses in disease. Scotian Press, London, p 17-18

Fernández L, Méndez J, Guijarro JA (2007) Molecular virulence mechanisms of the fish pathogen Yersinia ruckeri. Vet Microbiol 125:1-10

Fouz B, Zarza C, Amaro C (2006) First description of nonmotile Yersinia ruckeri serovar I strains causing disease in rainbow trout, Oncorhynchus mykiss (Walbaum), cultured in Spain. J Fish Dis 29:339-346

Furones MD, Rodgers CJ, Munn CB (1993) Yersinia ruckeri, the causal agent of enteric redmouth disease (ERM) in fish. Annu Rev Fish Dis 3:105-125

Gibello A, Blanco MM, Moreno MA, Cutuli MT, Domenech A, Dominguez L, Fernandez-Garayzabal JF (1999) Development of a PCR assay for detection of Yersinia ruckeri in tissues of inoculated and naturally infected trout. Appl Environ Microbiol 65:346-350

Ling SHM, Wang XH, Lim TM, Leung KY (2001) Green fluorescent protein-tagged Edwardsiella tarda reveals portal of entry in fish. FEMS Microbiol Lett 194:239-243

- Matsuo K, Ota H, Akamatsu T, Sugiyama A, Katsuyana T (1997) Histochemistry of the surface mucous gel layer of the human colon. Gut 40:782-789

McIntosh D, Austin B, Flaño E, Villena A, Martínez-Pereda JA, Tarazona JV (2000) Lack of uptake of Renibacterium salmoninarum by gill epithelia of rainbow trout. J Fish Biol 56:1053-1061

Nikoskelainen S, Bylund G, Lilius EM (2004) Effect of environmental temperature on rainbow trout (Oncorhynchus mykiss) innate immunity. Dev Comp Immunol 28:581-592

> Ota H, Katsuyama T (1992) Alternating laminated array of two types of mucin in the human gastric surface mucous layer. Histochem J 24:86-92

> Passantino L, Altamura M, Cianciotta A, Patruno R, Tafaro A, Jirillo E, Passantino GF (2002) Fish immunology. I. Binding 
and engulfment of Candida albicans by erythrocytes of rainbow trout (Salmo gairdneri Richardson). Immunopharmacol Immunotoxicol 24:665-678

Roberts MS (1983) A report of an epizootic in hatchery reared rainbow trout, Salmo gairdneri Richardson, at an English trout farm, caused by Yersinia ruckeri. J Fish Dis 6: 551-552

Romalde JL, Toranzo AE (1993) Pathological activities of Yersinia ruckeri, the enteric redmouth (ERM) bacterium. FEMS Microbiol Lett 112:291-300

Shimizu T, Akamatsu T, Ota H, Katsuyama T (1996) Immunohstochemical detection of Helicobacter pylori in the surface mucous gel layer and its clinicopathological significance. Helicobacter 1:197-206

Spanggaard B, Huber I, Nielsen J, Nielsen T, Gram L (2000)

Editorial responsibility: David Bruno,

Aberdeen, UK
Proliferation and location of Vibrio anguillarum during infection of rainbow trout, Oncorhynchus mykiss (Walbaum). J Fish Dis 23:423-427

Torroba M, Anderson DP, Dixon OW, Casares F and others (1993) In vitro antigen trapping by gill cells of the rainbow trout-an immunohistochemical study. Histol Histopathol 8:363-367

Valtonen ET, Rintamäki P, Koskivaara M (1992) Occurence and pathogenicity of Yersinia ruckeri at fish farms in northern and central Finland: Do wild fish serve as a source of infection? J Fish Dis 15:163-171

Zapata AG, Torroba M, Alvarez F, Anderson DP, Dixon OW, Wisniewski M (1987) Electron microscopic examination of antigen uptake by salmonid gill cells after bath immunization with a bacterin. J Fish Biol 31:209-217

Submitted: August 15, 2008; Accepted: March 5, 2009

Proofs received from author(s): April 19, 2009 